\title{
Quality Awareness - An Imperative Need for Flourishing Knitwear Industry in India.
}

\author{
S. Shanmugasundaram, ${ }^{* *} \mathrm{G}$. Loganathan, ${ }^{* * *}$ Dr. N. Panchanatham
}

\begin{abstract}
Till 1979, the knitwear was otherwise known as Hosiery which is mean to be only under garments such as Vest and Brief mainly used by Men in India. Later, knitwear products were identified as a fashionable product by the fashion industries of western countries, resulting in plain "T. Shirts" are made as a pioneer product of fashion in Indian Knitwear industry. In the process of evolution, the knitwear products reached different dimensions according to human anatomy, makes the knitwear products with highly fashionable, embellished and comfort to wear. At this juncture the consumers of western countries, realized that the quality of knitwear products are forced to seek and implement new techniques and methods to maintain durability, colour fastness, harmless chemicals etc,. Consequently, stringent quality policy such as ISO 9000, ISO 9002, SA 8000, TOTAL QUALITY MANAGEMNT (TQM) etc., were implemented in the knitwear industry all over the world. But implementing such systems in the Indian knitwear industries are cumbersome because the textile industry in India considered as by product of agricultural industries where great lack of quality awareness was found greatly, besides many other factors such as lack of unskilled executives and workers, lack of coordination between government and knitwear industries and educational institutions stood as a bottleneck for quality awareness, which is an urgent and imperative need of the knitwear industries to flourish in India.
\end{abstract}

\section{INTRODUCTION}

Recent years, "The Hosiery is meant to be worn as next to skin but was never to be seen" and this was the concept of the people all over the world. But now the scope has been widened much throughout the world. A revolution in fashions in dress is taking place entire world. The tycoon of today are no longer a prisoner of the 3 piece suits instead he enjoys it at work in some bright loose and comfortable knitwear much contrasting to the aforesaid concept.

However now the textile scenario has been reversed with the south especially when Tirupur taking the lead. During the year 1927 first manually operated hosiery factory with entire installation of organized machineries was triggered in the small town called in Coimbatore district. Tirupur, the heartland of the knitwear industries of India has a supplier base which consists essentially of manufacturers who are mostly integrated forward or backward if not vertical. There

*S. Shanmugasundaram, Assistant professor, department of Business Administration, Annamalai University, Annamalai Nagar. India.

**G. Loganathan, diector, The Imperial, an apparels sourcing Inc,. Tirupur, India.

***Dr. N. Panchanatham Professor \& Head, department of Business Administration, Annamalai University, Annamalai Nagar. India are number of spinners of yarn integrating forward to set up knitting plant; textile process house and then further integrating forward to become makers of garments. The amount of investments in terms of plant \& machinery and overheads in the integrated garment industry is quite high as compared to other knitwear clusters and thus requires efficient management for timely return on investments. In spite of the fact that the Tirupur town is reeling under due to acute infrastructural shortage, knitwear exporters are able to make a distinct mark in the international sourcing map of the textile industries for they worked as a group and helped each others for a common cause. Tirupur textile industry has units all along the value chain of knitwear starting from spinning, knitting wet processing, printing, garment manufacturing and exports. Entire Tirupur cluster generates direct employment for over 300,000 persons. During 1981 Tirupur had very meager share of $15 \%$ of the total knitwear exports from India and by the year 2000 its shares reached a formidable figure of $51 \%$. Now the industry has spread over magnificently upto 4500 units covering $80 \%$ of total knitwear exports of India and thus earning huge amount of foreign exchange for our country. It is expected that Tirupur exports will grow much faster and higher than the rest of India's export economy.

\section{REVIEWS}

For every industry or business, to get increased sales and better name amongst consumers and fellow companies it is important to maintain a level of quality. Especially for the businesses engaged in export business has to sustain a high level of quality to ensure better business globally. Generally quality control standards for export are set strictly, as this business is also holds the prestige of the country, whose company is doing the export. In the garment industry quality control is practiced right from the initial stage of sourcing raw materials to the stage of final finished garment. The process of the garment Industry, and the pros and cons of each process was analysed and it was suggested that one has to maintain the quality of the garment before and after processing in order to place it in front of the customer with an attractive look through value additions (Saumyen Mapdar, 2002). For textile and apparel industry product quality is calculated in terms of quality and standard of fibres, yarns, fabric construction, colour fastness, surface designs and the final finished garment products. The quality is testing as an instrument for process improvement and quality up gradation (Nadiger, 2001). There are a number of factors on which quality fitness of garment industry is based such as - 
performance, reliability, durability, visual and perceived quality of the garment. The latest developments in processing of knitted fabric and the benefits of technologies in improving the quality of product (Edwyn Rodrigues, 2000). Quality needs to be defined in terms of a particular frame $\neg$ work of cost. The national regulatory quality certification and international quality programmes like ISO 9000 series lay down the broad quality parameters based on which companies maintain the export quality in the garment and apparel industry. Reddy (2002) attempted an analysis of SWOTs of Indian textiles and clothing industries and the requirements for quality, environment and social responsibility standards and suggested a strategy towards global competitiveness. It was focused how the companies can achieve operational efficiency and profitability by the way of implementation of standards like ISO 9000, ISO 14000 and SA 8000. Quality is ultimately a question of customer satisfaction. Good Quality increases the value of a product or service, establishes brand name, and builds up good reputation for the garment exporter, which in turn results into consumer satisfaction, high sales and foreign exchange for the country. The perceived quality of a garment is the result of a number of aspects, which together help achieve the desired level of satisfaction for the customer. Therefore quality control in terms of garment, pre-sales service, posts -sales service, delivery, pricing, etc are essentials for any garment exporter (Gaurav Doshi, 2006).

\section{OBJECTIVES OF THE STUDY}

The study is carried out with the following Objectives and determination. 1. To Analysis the different levels of Management about QMS development. 2. To examine the administrative frame work in knitwear industries QMS. 3. To study Government agencies and other agencies appraisal role in knitwear industries QMS. 4. To provide suggestions, recommendations and conclusion for the improvement of QMS and also scope for further studies.

\section{Methodology}

The study has used both primary and secondary data. But mostly it has been based primary data collected through questionnaires, interviews etc. middle management and top management officials and other level of management. Strategically random sampling method was used for selecting samples in the case of management officials for collection of primary data. As far as management officials were concerned the total population was 2000 out of which 200 were selected as sample under stratified random sampling method. For this the total population was stratified into different groups like top level officials, middle level officials and lower level officials. The methodology adopted is a scientific and objective one without any personal bias.

The below Table No.1 explain the respondents opinion about Quality Management System (QMS) in lower level management with respect to age of lower level mgt, importance of lower level, critical evaluation of lower level qms, government role in achieving effective qms based on awareness Criteria. One-way ANOVA has been applied to find out the variance of opinion relating to these factors based on awareness Criteria.

TABLE: 1 ANOVA BETWEEN AWARENESS AND DIMENSIONS OF JOB QUALITY MANAGEMENT SYSTEM IN LOWER LEVEL MANAGEMENT.

\begin{tabular}{|c|c|c|c|c|c|c|}
\hline & & $\begin{array}{l}\text { Sum of } \\
\text { Squares }\end{array}$ & $\mathrm{df}$ & Mean Square & $\mathrm{F}$ & Sig. \\
\hline \multirow{3}{*}{$\begin{array}{c}\text { AGE OF LOWER LEVEL } \\
\text { MGT IN QMS }\end{array}$} & Between Groups & 1.761 & 1 & 1.761 & \multirow{3}{*}{5.231} & \multirow{3}{*}{.024} \\
\hline & Within Groups & 32.989 & 98 & .337 & & \\
\hline & Total & 34.750 & 99 & & & \\
\hline \multirow{3}{*}{$\begin{array}{l}\text { IMPORTANCE OF QMS } \\
\text { IN LOWER LEVEL MGT. }\end{array}$} & Between Groups & 5.290 & 1 & 5.290 & \multirow{3}{*}{6.182} & \multirow{3}{*}{.015} \\
\hline & Within Groups & 83.870 & 98 & .856 & & \\
\hline & Total & 89.160 & 99 & & & \\
\hline \multirow{3}{*}{$\begin{array}{c}\text { CRITICAL } \\
\text { EVALUATION OF QMS } \\
\text { IN LOWER LEVEL MGT. }\end{array}$} & Between Groups & 10.908 & 1 & 10.908 & \multirow{3}{*}{20.695} & \multirow{3}{*}{.000} \\
\hline & Within Groups & 51.652 & 98 & .527 & & \\
\hline & Total & 62.560 & 99 & & & \\
\hline \multirow{3}{*}{$\begin{array}{l}\text { GOVERNMENT ROLE } \\
\text { IN ACHIEVING QMS IN } \\
\text { LOWER LEVEL MGT. }\end{array}$} & Between Groups & 30.245 & 1 & 30.245 & \multirow{3}{*}{90.520} & \multirow{3}{*}{.000} \\
\hline & Within Groups & 32.745 & 98 & .334 & & \\
\hline & Total & 62.990 & 99 & & & \\
\hline
\end{tabular}

From the significant value it is observed that there is significant relationship between age of lower level mgt and awareness of qms (.024), there is significant relationship between importance of lower level and awareness of qms (.015), there is highly significant relationship between critical evaluation of lower level qms and awareness of qms (.000) and there is highly significant relationship between government role in achieving effective qms and awareness of qms (.000).
The below Table No.2 explain the respondents opinion about Quality Management System (QMS) in middle level management with respect to age of middle level mgt, importance of middle level, critical evaluation of middle level qms, government role in achieving effective qms based on awareness Criteria. One-way ANOVA has been applied to find out the variance of opinion relating to these factors based on awareness Criteria. 
TABLE: 2 ANOVA BETWEEN AWARENESS AND DIMENSIONS OF JOB QUALITY MANAGEMENT SYSTEM IN MIDDLE LEVEL MANAGEMENT.

\begin{tabular}{|c|c|c|c|c|c|c|}
\hline & & $\begin{array}{l}\text { Sum of } \\
\text { Squares }\end{array}$ & df & Mean Square & $\mathrm{F}$ & Sig. \\
\hline \multirow{3}{*}{$\begin{array}{l}\text { AGE OF MIDDLE LEVEL } \\
\text { MGT IN QMS }\end{array}$} & Between Groups & 5.188 & 1 & 5.188 & \multirow{3}{*}{15.502} & \multirow{3}{*}{.000} \\
\hline & Within Groups & 19.412 & 58 & .335 & & \\
\hline & Total & 24.600 & 59 & & & \\
\hline \multirow{3}{*}{$\begin{array}{l}\text { IMPORTANCE OF QMS } \\
\text { IN MIDDLE LEVEL } \\
\text { MGT. }\end{array}$} & Between Groups & 8.897 & 1 & 8.897 & \multirow{3}{*}{8.945} & \multirow{3}{*}{.004} \\
\hline & Within Groups & 57.686 & 58 & .995 & & \\
\hline & Total & 66.583 & 59 & & & \\
\hline \multirow{3}{*}{$\begin{array}{c}\text { CRITICAL } \\
\text { EVALUATION OF QMS } \\
\text { IN MIDDLE LEVEL } \\
\text { MGT. }\end{array}$} & Between Groups & 40.262 & 1 & 40.262 & \multirow{3}{*}{40.316} & \multirow{3}{*}{.000} \\
\hline & Within Groups & 57.922 & 58 & .999 & & \\
\hline & Total & 98.183 & 59 & & & \\
\hline \multirow{3}{*}{$\begin{array}{l}\text { GOVERNMENT ROLE } \\
\text { IN ACHIEVING QMS IN } \\
\text { MIDDLE LEVEL MGT. }\end{array}$} & Between Groups & 24.894 & 1 & 24.894 & \multirow{3}{*}{72.052} & \multirow{3}{*}{.000} \\
\hline & Within Groups & 20.039 & 58 & .346 & & \\
\hline & Total & 44.933 & 59 & & & \\
\hline
\end{tabular}

From the significant value it is observed that there highly is significant relationship between age of middle level mgt and awareness of qms (.000), there is high significant relationship between importance of middle level and awareness of qms (.000), there is high significant relationship between critical evaluation of middle level qms and awareness of qms (.000) and there is highly significant relationship between government role in achieving effective qms and awareness of qms (.000).

The below Table No.3 explain the respondents opinion about Quality Management System (QMS) with respect to age of top level mgt, importance of top level, critical evaluation of top level qms, government role in achieving effective qms based on awareness Criteria. One-way ANOVA has been applied to find out the variance of opinion relating to these factors based on awareness Criteria.

From the below Table No.3 significant value it is observed that there highly is significant relationship between age of top level mgt and awareness of qms (.000), there highly is significant relationship between importance of top level and awareness of qms (.000), there is highly significant relationship between critical evaluation of top level qms and awareness of qms (.000) and there is significant relationship between government role in achieving effective qms and awareness of qms (.025).

TABLE: 3 ANOVA BETWEEN AWARENESS AND DIMENSIONS OF JOB QUALITY MANAGEMENT SYSTEM IN TOP LEVEL MANAGEMENT.

\begin{tabular}{|c|c|c|c|c|c|c|}
\hline & & $\begin{array}{l}\text { Sum of } \\
\text { Squares }\end{array}$ & $\mathrm{df}$ & Mean Square & $\mathrm{F}$ & Sig. \\
\hline \multirow{3}{*}{$\begin{array}{l}\text { AGE OF TOP LEVEL } \\
\text { MGT IN QMS }\end{array}$} & Between Groups & 10.000 & 1 & 10.000 & \multirow{3}{*}{63.333} & \multirow{3}{*}{.000} \\
\hline & Within Groups & 6.000 & 38 & .158 & & \\
\hline & Total & 16.000 & 39 & & & \\
\hline \multirow{3}{*}{$\begin{array}{l}\text { IMPORTANCE OF QMS } \\
\text { IN TOP LEVEL MGT. }\end{array}$} & Between Groups & 11.556 & 1 & 11.556 & \multirow{3}{*}{17.413} & \multirow{3}{*}{.000} \\
\hline & Within Groups & 25.219 & 38 & .664 & & \\
\hline & Total & 36.775 & 39 & & & \\
\hline \multirow{3}{*}{$\begin{array}{c}\text { CRITICAL } \\
\text { EVALUATION OF QMS } \\
\text { IN TOP LEVEL MGT. }\end{array}$} & Between Groups & 36.100 & 1 & 36.100 & \multirow{3}{*}{58.374} & \multirow{3}{*}{.000} \\
\hline & Within Groups & 23.500 & 38 & .618 & & \\
\hline & Total & 59.600 & 39 & & & \\
\hline \multirow{3}{*}{$\begin{array}{l}\text { GOVERNMENT ROLE } \\
\text { IN ACHIEVING QMS IN } \\
\text { TOP LEVEL MGT. }\end{array}$} & Between Groups & 2.756 & 1 & 2.756 & \multirow{3}{*}{5.450} & \multirow{3}{*}{.025} \\
\hline & Within Groups & 19.219 & 38 & .506 & & \\
\hline & Total & 21.975 & 39 & & & \\
\hline
\end{tabular}


TABLE: 8 CORRELATION OF QUALITY MANAGEMENT SYSTEM AND ITS DIMENSIONS IN TOP LEVEL MANAGEMENT.

\begin{tabular}{|c|c|c|c|c|c|}
\hline & & $\begin{array}{l}\text { AWARENESS } \\
\text { OF QMS IN TOP } \\
\text { LEVEL MGT }\end{array}$ & $\begin{array}{l}\text { IMPORTANCE } \\
\text { OF QMS IN TOP } \\
\text { LEVEL MGT. }\end{array}$ & $\begin{array}{c}\text { CRITICAL } \\
\text { EVALUATION } \\
\text { OF QMS IN TOP } \\
\text { LEVEL MGT }\end{array}$ & $\begin{array}{c}\text { GOVERNMENT } \\
\text { ROLE IN } \\
\text { ACHIEVING } \\
\text { QMS IN TOP } \\
\text { LEVEL MGT }\end{array}$ \\
\hline \multirow{3}{*}{$\begin{array}{l}\text { AWARENESS OF QMS IN } \\
\text { TOP LEVEL MGT }\end{array}$} & Pearson Correlation & \multirow[b]{3}{*}{40} & $.561(* *)$ & $.778(* *)$ & $.354\left(^{*}\right)$ \\
\hline & Sig. (2-tailed) & & .000 & .000 & .025 \\
\hline & $\mathrm{N}$ & & 40 & 40 & 40 \\
\hline \multirow{3}{*}{$\begin{array}{l}\text { IMPORTANCE OF QMS IN } \\
\text { TOP LEVEL MGT. }\end{array}$} & Pearson Correlation & \multirow{3}{*}{$\begin{array}{c}.561(* *) \\
.000 \\
40\end{array}$} & \multirow[b]{3}{*}{40} & $.818(* *)$ & $.8599^{(* *)}$ \\
\hline & Sig. (2-tailed) & & & .000 & .000 \\
\hline & $\overline{\mathrm{N}}$ & & & 40 & 40 \\
\hline \multirow{3}{*}{$\begin{array}{c}\text { CRITICAL EVALUATION } \\
\text { OF QMS IN TOP LEVEL } \\
\text { MGT. }\end{array}$} & Pearson Correlation & \multirow{3}{*}{$\begin{array}{c}.778(* *) \\
.000\end{array}$} & \multirow{2}{*}{$\begin{array}{c}.818(* *) \\
.000\end{array}$} & \multirow[t]{2}{*}{1} & \multirow{2}{*}{$\begin{array}{c}.666(* *) \\
.000\end{array}$} \\
\hline & Sig. (2-tailed) & & & & \\
\hline & $\mathrm{N}$ & & 40 & 40 & 40 \\
\hline \multirow{3}{*}{$\begin{array}{l}\text { GOVERNMENT ROLE IN } \\
\text { ACHIEVING QMS IN TOP } \\
\text { LEVEL MGT. }\end{array}$} & Pearson Correlation & \multirow{3}{*}{$\begin{array}{c}.354(*) \\
.025 \\
40\end{array}$} & \multirow{3}{*}{$\begin{array}{c}.859(* *) \\
.000 \\
40\end{array}$} & \multirow{3}{*}{$\begin{array}{c}.666(* *) \\
.000 \\
40\end{array}$} & \multirow[t]{2}{*}{1} \\
\hline & Sig. (2-tailed) & & & & \\
\hline & $\mathrm{N}$ & & & & 40 \\
\hline
\end{tabular}

** Correlation is significant at the 0.01 level (2-tailed). * Correlation is significant at the 0.05 level (2-tailed).

The above table shows the correlation of Quality management system among top level mgt, importance of top level, critical evaluation of top level qms and government role in achieving effective qms. The dependent variable is found to have positive and significant relationship with all the other dimensions. All the independent variables are also found to have positive and significant relationship with each other.

\begin{tabular}{|c|c|c|c|c|c|}
\hline & & $\begin{array}{l}\text { AWARENESS } \\
\text { OF QMS IN } \\
\text { MIDDLE } \\
\text { LEVEL MGT }\end{array}$ & $\begin{array}{l}\text { IMPORTANCE } \\
\text { OF QMS IN } \\
\text { MIDDLE } \\
\text { LEVEL MGT. }\end{array}$ & $\begin{array}{c}\text { CRITICAL } \\
\text { EVALUATION } \\
\text { OF QMS IN } \\
\text { MIDDLE LEVEL } \\
\text { MGT. }\end{array}$ & $\begin{array}{c}\text { GOVERNMENT } \\
\text { ROLE IN } \\
\text { ACHIEVING } \\
\text { QMS IN } \\
\text { MIDDLE LEVEL } \\
\text { MGT. }\end{array}$ \\
\hline \multirow{4}{*}{$\begin{array}{l}\text { AWARENESS OF QMS IN } \\
\text { MIDDLE LEVEL MGT }\end{array}$} & Pearson Correlation & \multirow[t]{3}{*}{1} & $.244(*)$ & $.418(* *)$ & $.693(* *)$ \\
\hline & Sig. (2-tailed) & & \multirow[b]{2}{*}{.015} & \multirow{2}{*}{.000} & \multirow{2}{*}{.000} \\
\hline & \multirow[t]{2}{*}{$\mathrm{N}$} & & & & \\
\hline & & 100 & 100 & 100 & 100 \\
\hline \multirow{4}{*}{$\begin{array}{l}\text { IMPORTANCE OF QMS IN } \\
\text { MIDDLE LEVEL MGT. }\end{array}$} & Pearson Correlation & $.244(*)$ & 1 & $.866(* *)$ & $.531(* *)$ \\
\hline & Sig. (2-tailed) & \multirow[b]{2}{*}{.015} & \multirow[b]{2}{*}{. } & \multirow[b]{2}{*}{.000} & \multirow[b]{2}{*}{.000} \\
\hline & $\mathrm{N}$ & & & & \\
\hline & & 100 & 100 & 100 & 100 \\
\hline \multirow{3}{*}{$\begin{array}{l}\text { CRITICAL EVALUATION } \\
\text { OF QMS IN MIDDLE } \\
\text { LEVEL MGT. }\end{array}$} & Pearson Correlation & \multirow{2}{*}{$\begin{array}{c}.418(* *) \\
.000\end{array}$} & \multirow{2}{*}{$\begin{array}{c}.866(* *) \\
.000\end{array}$} & 1 & $.639(* *)$ \\
\hline & Sig. (2-tailed) & & & \multirow[b]{2}{*}{100} & .000 \\
\hline & $\mathrm{N}$ & 100 & 100 & & 100 \\
\hline \multirow{3}{*}{$\begin{array}{l}\text { GOVERNMENT ROLE IN } \\
\text { ACHIEVING QMS IN } \\
\text { MIDDLE LEVEL MGT. }\end{array}$} & Pearson Correlation & \multirow{2}{*}{$\begin{array}{c}.693(* *) \\
.000\end{array}$} & \multirow{2}{*}{$\begin{array}{c}.531(* *) \\
.000\end{array}$} & \multirow{2}{*}{$\begin{array}{c}.639(* *) \\
.000\end{array}$} & 1 \\
\hline & Sig. (2-tailed) & & & & . \\
\hline & $\mathrm{N}$ & 100 & 100 & 100 & 100 \\
\hline
\end{tabular}

* Correlation is significant at the 0.05 level (2-tailed). ** Correlation is significant at the 0.01 level (2-tailed).

The above table shows the correlation of Quality management system among middle level mgt, importance of top level, critical evaluation of top level qms and government role in achieving effective qms. The dependent variable is found to have positive and significant relationship with all the other dimensions. All the independent variables are also found to have positive and significant relationship with each other. 
TABLE: 5 CORRELATION OF QUALITY MANAGEMENT SYSTEM AND ITS DIMENSIONS IN LOWER LEVEL MANAGEMENT.

\begin{tabular}{|c|c|c|c|c|c|}
\hline & & $\begin{array}{l}\text { AWARENESS } \\
\text { OF QMS IN } \\
\text { MIDDLE } \\
\text { LEVEL MGT }\end{array}$ & $\begin{array}{l}\text { IMPORTANCE } \\
\text { OF QMS IN } \\
\text { MIDDLE } \\
\text { LEVEL MGT. }\end{array}$ & $\begin{array}{c}\text { CRITICAL } \\
\text { EVALUATION } \\
\text { OF QMS IN } \\
\text { MIDDLE LEVEL } \\
\text { MGT }\end{array}$ & $\begin{array}{l}\text { GOVERNMENT } \\
\text { ROLE IN } \\
\text { ACHIEVING } \\
\text { QMS IN } \\
\text { MIDDLE LEVEL } \\
\text { MGT. }\end{array}$ \\
\hline \multirow{3}{*}{$\begin{array}{l}\text { AWARENESS OF QMS IN } \\
\text { MIDDLE LEVEL MGT }\end{array}$} & Pearson Correlation & \multirow[t]{3}{*}{1} & $.244(*)$ & $.418(* *)$ & $.693(* *)$ \\
\hline & Sig. (2-tailed) & & .015 & .000 & .000 \\
\hline & $\mathrm{N}$ & & 100 & 100 & 100 \\
\hline \multirow{3}{*}{$\begin{array}{l}\text { IMPORTANCE OF QMS IN } \\
\text { MIDDLE LEVEL MGT. }\end{array}$} & Pearson Correlation & $.244(*)$ & 1 & $.866(* *)$ & $.531(* *)$ \\
\hline & Sig. (2-tailed) & .015 & . & .000 & .000 \\
\hline & $\mathrm{N}$ & 100 & 100 & 100 & 100 \\
\hline \multirow{3}{*}{$\begin{array}{c}\text { CRITICAL EVALUATION } \\
\text { OF QMS IN MIDDLE } \\
\text { LEVEL MGT. }\end{array}$} & Pearson Correlation & \multirow{3}{*}{$\begin{array}{r}.418(* *) \\
.000\end{array}$} & $.866(* *)$ & \multirow[b]{3}{*}{100} & \multirow{3}{*}{$\begin{array}{r}.639(* *) \\
.000\end{array}$} \\
\hline & Sig. (2-tailed) & & .000 & & \\
\hline & $\mathrm{N}$ & & 100 & & \\
\hline \multirow{3}{*}{$\begin{array}{l}\text { GOVERNMENT ROLE IN } \\
\text { ACHIEVING QMS IN } \\
\text { MIDDLE LEVEL MGT. }\end{array}$} & Pearson Correlation & \multirow{3}{*}{$\begin{array}{r}.693(* *) \\
.000 \\
100\end{array}$} & $.531(* *)$ & \multirow{3}{*}{$\begin{array}{r}.639(* *) \\
.000 \\
100\end{array}$} & \multirow[t]{2}{*}{1} \\
\hline & Sig. (2-tailed) & & .000 & & \\
\hline & $\mathrm{N}$ & & 100 & & 100 \\
\hline
\end{tabular}

The above table shows the correlation of Quality management system among Lower level mgt, importance of top level, critical evaluation of top level qms and government role in achieving effective qms. The dependent variable is found to have positive and significant relationship with all the other dimensions. All the independent variables are also found to have positive and significant relationship with each other.

\section{SugGestions AND RECOMMENDATIONS}

Machineries and equipments with advanced sophisticated modern technology should be used widely on a large scale by all the units in Tirupur, so as to improve quality, productivity and also to detect, rectify errors at every stage. The Government should evolve clear guidelines and standards especially with regard to QMS for each and every knitwear unit. The standardisation of quality at each stage should be made compulsory by the Government for every single unit, should not allow any such units to function and must comply with the required standards as specified by QMS at all stages.

The Government should send periodical inspection team on a regular basis to the units to ensure the proper QMS. The Government should also be more generous to grand sufficient financial assistance and supports to the knitwear units in the form of subsidies and provision of technical' know-how as a measure of guidance for marketing and export etc. The Government should also resort to develop the industries with reference to QMS by active collaboration with NIFT, other voluntary agencies like TEA and also with the local manufacturers and exporters.

The Government agencies with the support and co-operation of voluntary agencies and exporters association shall conduct seminars, conferences, orientation programmes, training programmes for the people involved in different levels of management and also for labourers, with special focus on QMS and its importance.

\section{CONCLUSION}

The study has ascertained that the lack of quality consciousness and awareness in the knitwear industries in Tirupur and also unawareness in the different levels of management. The Yearn of inferior quality are chosen due to the cost factor at the initial stage itself without compromising the quality aspects. Though the manual knitting has become completely obsolete in the knitwear industries in Tirupur, most of the units use indigenous machineries for their knitting in performance. As a result, the fabrics became much inferior in quality and also resulted in large wastages.

Due to want of time and mounted over pressure and urge for executing out the order on time, most of the manufacturers fail to check the quality of the fabrics at the initial stage itself. Due to this factor inferior quality fabric goes for the next stage of further processing and finishing which causes unwanted processing cost increasing the total value of the piece. The study also finds that the role of Government agencies in lending of assistance to the knitwear industry is very low, which has led to contravention and most of the manufacturers never comply the quality and standards and other specifications. They never try to attempt with the efforts for any fulfillments that are expected.

\section{REFERENCES}

[1] apparel.indiamart.com/lib/garments/indian07251998.html

[2] Apparel Views Report, “Are we Using Right Technology for Apparel Production?,”. Apparel views Feb. 2003:1-2.

[3] Edwyn Rodrigues. " Knit Fabrics Principle and Recent Developments in Processing”, Clothesline Nov. $2000: 74$.

[4] Jalaludin MSS, "Quality System and Products Specifications Knitted Garments,” Indus League Clothing Limited July. 2002.

[5] Nadiger. G.S, "Testing As An Instrument for Process Improvement and Quality Upgradationm,” Textile committee Oct. 2001:99.

[6] Official website of Ministry of Textiles,Government of India, http://texmin.nic.in, 2005. 
[7] Reddy,R.C.M. "Global Competitiveness of Indian Textiles Perspectives on Quality and Standards," Quality and Complaiances, Spec. Issue of Textile Committee March. 2002: 53

[8] Saumyen mapdar, "Introspection into Garments Dyeing," 3Ts A Journal of Textile Committee April - June. 2002:5

[9] Shanmugasundaram S and Panchanatham N,"Export Challenges in Tamil Nadu Garment Industry", Synthesis June 2007:67

[10] Shanmugasundaram S and Panchanatham N,"Global Challenges in Tamil Nadu Garment Industry", International Journal of Management Sciences dec.2007:127 $--\mathrm{X}-$ 